\title{
Cannabidiol as a Potential New Type of an Antipsychotic. A Critical Review of the Evidence
}

\author{
Cathrin Rohleder, Juliane K. Müller, Bettina Lange and F. M. Leweke* \\ Department of Psychiatry and Psychotherapy, Central Institute of Mental Health, Medical Faculty Mannheim, Heidelberg \\ University, Mannheim, Germany
}

\section{OPEN ACCESS}

Edited by:

José Alexandre Crippa,

University of São Paulo, Brazil

Reviewed by:

Jose M. Trigo,

Centre for Addiction and Mental

Health, Canada

Fabricio A. Moreira,

Federal University of Minas Gerais,

Brazil

${ }^{*}$ Correspondence:

F. M. Leweke leweke@cimh.de

Specialty section:

This article was submitted to

Neuropharmacology,

a section of the journal

Frontiers in Pharmacology

Received: 29 July 2016

Accepted: 24 October 2016

Published: 08 November 2016

Citation:

Rohleder C, Müller JK, Lange B and

Leweke FM (2016) Cannabidiol as

a Potential New Type of an

Antipsychotic. A Critical Review of the

Evidence. Front. Pharmacol. 7:422.

doi: 10.3389/fphar.2016.00422
There is urgent need for the development of mechanistically different and less side-effect prone antipsychotic compounds. The endocannabinoid system has been suggested to represent a potential new target in this indication. While the chronic use of cannabis itself has been considered a risk factor contributing to the development of schizophrenia, triggered by the phytocannabinoid delta-9-tetrahydrocannabinol ( $\left.\Delta^{9}-\mathrm{THC}\right)$, cannabidiol, the second most important phytocannabinoid, appears to have no psychotomimetic potential. Although, results from animal studies are inconsistent to a certain extent and seem to depend on behavioral paradigms, treatment duration and experimental conditions applied, cannabidiol has shown antipsychotic properties in both rodents and rhesus monkeys. After some individual treatment attempts, the first randomized, doubleblind controlled clinical trial demonstrated that in acute schizophrenia cannabidiol exerts antipsychotic properties comparable to the antipsychotic drug amisulpride while being accompanied by a superior, placebo-like side effect profile. As the clinical improvement by cannabidiol was significantly associated with elevated anandamide levels, it appears likely that its antipsychotic action is based on mechanisms associated with increased anandamide concentrations. Although, a plethora of mechanisms of action has been suggested, their potential relevance for the antipsychotic effects of cannabidiol still needs to be investigated. The clarification of these mechanisms as well as the establishment of cannabidiol's antipsychotic efficacy and its hopefully benign side-effect profile remains the subject of a number of previously started clinical trials.

Keywords: schizophrenia, psychosis, animal models, clinical trials, CBD

\section{INTRODUCTION}

Cannabis sativa has been known and used by humans for several 1000 years and the knowledge that it contains an intoxicating principle dates back to 1000 to 1500 B.C. (Adams, 1942). The two major compounds of cannabis - delta-9-tetrahydrocannabinol $\left(\Delta^{9}\right.$-THC) and cannabidiol have been chemically identified in the 1940th (Adams et al., 1940a,b,c; Adams, 1942; Todd, 1946). Two decades later, remaining uncertainties regarding the exact position of double bonds were eliminated as new imaging techniques like NMR spectroscopy and X-ray structure determination became available (Mechoulam and Shvo, 1963; Gaoni and Mechoulam, 1964; Jones et al., 1977).

Along with its chemical identification, $\Delta^{9}$-THC has been identified as the major propsychotic compound of Cannabis sativa (Adams and Baker, 1940; Adams et al., 1940b; Allentuck and Bowman, 1942; Wollner et al., 1942; Mechoulam et al., 1970). However, the underlying 
neurobiological principles remained conjectural until it was observed that cannabinoid drugs inhibit adenylate cyclase activity in neuroblastoma cells (Howlett, 1984), and the subsequent discovery of the G-protein coupled type 1 cannabinoid receptor $\left(\mathrm{CB}_{1} \mathrm{R}\right)$ (Devane et al., 1988; Matsuda et al., 1990). A few years later, the type 2 cannabinoid receptor $\left(\mathrm{CB}_{2} \mathrm{R}\right.$ ) (Munro et al., 1993) as well as the two major endogenous ligands to cannabinoid receptors - anandamide (Devane et al., 1992) and 2-arachidonoyl-sn-glycerol (Mechoulam et al., 1995; Stella et al., 1997) - were discovered. The architecture of the endocannabinoid system (ECS) - including endocannabinoids, cannabinoid receptors as well as synthesizing and degrading enzymes - has been vividly summarized and illustrated in recent reviews by Lutz et al. (2015) and Lu and Mackie (2016).

Studies indicating that cannabis abuse might be a stressor for psychotic relapse and exacerbation of schizophrenic symptoms as well as the observation that $\Delta^{9}$-THC induced schizophrenia-like neuropsychological and psychopathological alterations in healthy volunteers, led to the hypothesis that a dysfunctional ECS is involved in the etiology of psychoses (Emrich et al., 1997). In the meantime, several studies reported diverse acute $\Delta^{9}$-THC effects in healthy participants and schizophrenic patients, thereby confirming the ECS hypothesis (Leweke et al., 1999, 2000; D'Souza et al., 2004, 2005; Koethe et al., 2006; Bhattacharyya et al., 2009; Fusar-Poli et al., 2009; Koethe et al., 2009; Mason et al., 2009; Sherif et al., 2016). In addition, several epidemiological studies (for review see, Gage et al., 2016) substantiated the view that cannabis use has to be considered an important environmental risk factor for the development of schizophrenia in vulnerable individuals. However, the actual lifetime risk seems to be influenced by the dose (Zammit et al., 2002; Moore et al., 2007) and frequency of cannabis consumption (Di Forti et al., 2009), the potency of consumed cannabis preparations (Di Forti et al., 2009, 2014) and age of onset (Arseneault et al., 2002).

While a dysfunctional ECS seems to contribute to the pathophysiology of schizophrenia, the endocannabinoid anandamide is considered to have protective effects by counteracting neurotransmitter imbalances (Leweke, 2012). Therefore, it has been suggested that modulating the ECS might be a new, promising pharmacological target for schizophrenia.

To date, two main approaches targeting the ECS have been systematically studied in humans: first, trials using $\mathrm{CB}_{1} \mathrm{R}$ antagonists to treat both psychotic and cognitive symptoms of schizophrenia, and, second, trials using the second most important phytocannabinoid cannabidiol (Leweke et al., 2016). In addition, a single clinical case series on dronabinol ( $\Delta^{9}$-THC) in treatment-refractory severe chronic schizophrenia has been conducted (Schwarcz et al., 2009).

In contrast to $\Delta^{9}$-THC, cannabidiol appears to have no psychotomimetic potential, but shows antipsychotic effects in rodents and humans. Thus, this review focuses on (1) preclinical studies investigating cannabidiol as a potential antipsychotic in animal models of aspects of schizophrenia, (2) clinical evidence for its antipsychotic action, and, (3) potential mechanisms of action and their potential relevance for the antipsychotic effects of cannabidiol.

\section{METHODS}

We conducted a PubMed search up to and including June 28, 2016, using the search terms cannabidiol AND (antipsychotic OR schizophrenia OR psychosis). Identified references were scanned for clinical trials with schizophrenic patients as well as studies with animal models of aspects of schizophrenia, analyzing the effects of cannabidiol on negative symptoms and cognitive deficits. Studies restricted to analysis of locomotor activity or anxiety were not considered. In addition, we used the search term cannabidiol AND targets to scan for reports on the possible mode of action.

\section{ANTIPSYCHOTIC POTENTIAL OF CANNABIDIOL: INSIGHTS FROM PRECLINICAL STUDIES}

Schizophrenia is characterized by heterogeneous symptoms that can be grouped into three main symptom categories: (1) positive symptoms (delusions, thought disorder, hallucinations), (2) negative symptoms (anhedonia, blunted affect, social withdrawal) and (3) cognitive impairment (sensory information processing, attention, working memory, executive functions) (Freedman, 2003; Wong and Van Tol, 2003). These main symptoms are often accompanied by more unspecific symptoms like anxiety (Freedman, 2003).

Although psychotic symptoms are human specific to a large extent, animal models are able to provide insight into certain aspects of schizophrenia, including negative symptoms [e.g., inadequate social behavior/social withdrawal, sensorimotor gating deficits as measured by prepulse inhibition (PPI)], cognitive impairments (e.g., working memory deficits) or anxiety. Thus, these animal models for aspects of schizophrenia can be used to investigate the antipsychotic potential of new drugs like cannabidiol on negative and cognitive symptoms. As available antipsychotics do not sufficiently ameliorate negative symptoms and cognitive impairments (Hanson et al., 2010), these studies can make an important contribution.

Schizophrenia is not only characterized by a heterogeneous combination of symptoms but also by a heterogeneous etiology (Cannon and Jones, 1996; Brown, 2011; Kahn et al., 2015). This led to the development of animal models based on different etiological factors of schizophrenia. In the following, the concepts of animal models used to study the effects of cannabidiol are summarized in brief.

As mentioned above, cannabis use is regarded as one important risk factor for the development of schizophrenia. Hence, animal models of early cannabis exposure are used to investigate the long-lasting behavioral consequences of cannabis use and to clarify the underlying cellular mechanisms (Rubino and Parolaro, 2016). However, based on the observation that cannabis preparations or single cannabinoids like $\Delta^{9}$-THC induce psychotic-like symptoms in healthy volunteers (for review see Sherif et al., 2016), acute cannabinoid administration is also used to mimic schizophrenia-like symptoms in rodents. 
Furthermore, based on the hypothesis that disrupted glutamatergic neurotransmission contributes to the development of schizophrenia (Kim et al., 1980), pharmacological and genetic glutamatergic models have been used in cannabidiol research. Since this dysfunction is characterized by hypofunctional $N$-methyl-D-aspartic acid (NMDA) receptors (for review see Snyder and Gao, 2013), for example, NMDA receptor antagonists like MK-801 are administered to mimic schizophrenic-like symptoms in rodents. The genetic model is based on neuregulin 1, a susceptibility gene for schizophrenia (Stefansson et al., 2002). Neuregulin 1 is involved in neuronal migration, influences myelination and regulates expression of NMDA, $\gamma$-aminobuytric acid receptor $A\left(\mathrm{GABA}_{\mathrm{A}}\right)$ as well as acetylcholin receptor subunits (for review see Corfas et al., 2004). Heterozygous transmembrane Neuregulin 1 mutant mice (Nrg1 TM HET) seem to have fewer functional NMDA receptors (Stefansson et al., 2002), a region-specific alteration of NMDA receptor expression as well as decreased dopamine $\mathrm{D}_{2}$ receptor binding in the striatum (Newell et al., 2013). Interestingly, the $\mathrm{CB}_{1}$ receptor density is comparable to the density in wild type animals except for a slight increase within the striatum of Nrg1 TM HET (Newell et al., 2013).

The spontaneously hypertensive rat (SHR) strain has also been suggested as a model for aspects of schizophrenia. These rats show impaired social interaction (Calzavara et al., 2011; Almeida et al., 2014) and reduced PPI (Levin et al., 2011, 2014) as compared to Wistar rats. In addition, antipsychotic drugs reduced abnormalities in contextual fear conditioning (Calzavara et al., 2009), social interaction (Calzavara et al., 2011) as well as PPI (Levin et al., 2011). Nevertheless, other studies observed an increased PPI compared to Sprague Dawely rats (van den Buuse, 2004) or an increased social interaction behavior toward Wistar-Kyoto rats (Hopkins et al., 2009).

\section{Effects of Cannabidiol on Social Behavior}

Social withdrawal is a key negative symptom of schizophrenia. Thus, several studies investigated the effects of cannabidiol on social behavior in different rodent animal models for schizophrenia (Table 1).

Cannabidiol (dosage range: $1-50 \mathrm{mg} / \mathrm{kg}$ ) itself seems to have no effect on social interaction of untreated Sprague Dawley (Malone et al., 2009; Gururajan et al., 2012), Wistar rats (van Ree et al., 1984; Deiana et al., 2015), C57BL/6JArc mice (Long et al., 2010; Gomes et al., 2015b), and wild type-like littermates of Nrg1 TM HET mice (Long et al., 2012). However, in Wistar rats $1 \mathrm{mg} / \mathrm{kg}$ cannabidiol increased social interaction behavior, whereas higher dosages $(5,15,30,60 \mathrm{mg} / \mathrm{kg})$ had no effect (Almeida et al., 2013). In addition, impaired social memory was observed in Wistar rats (Deiana et al., 2015) after acute cannabidiol administration (12 and $30 \mathrm{mg} / \mathrm{kg}$, but not $5 \mathrm{mg} / \mathrm{kg}$ ).

The majority of studies reported that cannabidiol was able to attenuate or reverse induced altered social behavior. Pretreatment with $20 \mathrm{mg} / \mathrm{kg}$ cannabidiol reversed the effects of $1 \mathrm{mg} / \mathrm{kg}$ $\Delta^{9}$-THC (Malone et al., 2009), while $3 \mathrm{mg} / \mathrm{kg}$ cannabidiol inhibited the effects on social investigative behavior of acute MK801 treatment in a modified social interaction task, increasing it significantly beyond control level (Gururajan et al., 2012). This is in line with the previous finding of the group that cannabidiol (3, $10 \mathrm{mg} / \mathrm{kg}$ ) partially inhibited MK-801-induced social withdrawal in a classical social interaction paradigm (Gururajan et al., 2011). In mice, pretreatment with $60 \mathrm{mg} / \mathrm{kg}$ cannabidiol was found to reverse impaired social interaction induced by chronic MK-801 treatment, while a lower cannabidiol dose $(30 \mathrm{mg} / \mathrm{kg})$ attenuated the effects of MK-801 only by trend (Gomes et al., 2015b). As the antipsychotic clozapine also inhibited MK-801 effects on social investigative behavior, it has been suggested that cannabidiol might also be effective in schizophrenia patients showing inadequate social behaviors (Gururajan et al., 2012; Gomes et al., 2015b). However, cannabidiol did not reverse the social recognition impairments induced by an acute low-dose injection of MK-801 in Wistar rats. Furthermore, cannabidiol was not able to elevate the decreased social interaction of SHR rats (Almeida et al., 2013).

Although, Nrg1 TM HET mutant mice showed similar social behavior compared to their wild type-like littermates (Long et al., 2012), chronic cannabidiol treatment (50 mg/kg, 21 days) increased social interaction as well as specific social behaviors like nosing and anogenital sniffing in mutant mice but not in wild type mice. A higher cannabidiol dose $(100 \mathrm{mg} / \mathrm{kg})$ solely increased anogenital-sniffing duration in mutant mice, while lower concentrations ( $1 \mathrm{mg} / \mathrm{kg}$ ) led only to increasing nosing frequencies.

Taken together, cannabidiol showed antipsychotic properties in glutamatergic animal models as well as in a model targeting the ECS, whereas it has been ineffective in SHR rats.

\section{Effects of Cannabidiol on Prepulse Inhibition}

Prepulse inhibition of the acoustic startle response is a neuropsychological process during which a weak sensory stimulus - prepulse - attenuates the motor response to a subsequent strong startling stimulus (Rohleder et al., 2016). Since PPI impairments are observed in schizophrenia patients and PPI can be reliably assessed in both animals and humans, it has been used as behavioral measure of aspects of schizophrenia. Unfortunately, results from rodent studies analyzing the effects of cannabidiol on PPI and acoustic startle response in animal models of schizophrenia and untreated control rodents are inconsistent to a certain extent (Table 2).

The effects of cannabidiol on startle amplitude and PPI of healthy rodents seem to be not only dose- but also strain- and species-dependent. In male Swiss mice, cannabidiol $(15,30$, or $60 \mathrm{mg} / \mathrm{kg}$ ) did not affect PPI or startle amplitude (Pedrazzi et al., 2015). On the other hand, Long et al. (2006) reported that C57BL/6JArc mice acutely treated with cannabidiol (1 and 15 , but not $5 \mathrm{mg} / \mathrm{kg}$ ) showed increased startle amplitudes while PPI remained unaffected. In contrast, in wild type-like littermates of Nrg1 TM HET mice, acute treatment with low concentrations of cannabidiol ( 1 and $50 \mathrm{mg} / \mathrm{kg}$ ) as well as chronic cannabidiol treatment $(1,50,100 \mathrm{mg} / \mathrm{kg} ; 21$ days $)$ had no effect 
TABLE 1 | Animal studies evaluating the effects of cannabidiol (CBD) on social behavior.

\begin{tabular}{|c|c|c|c|}
\hline Animal model & $\begin{array}{l}\text { Treatment regimen and test } \\
\text { procedure }\end{array}$ & Effective dose [/kg] & Reference \\
\hline Spontaneously hypertensive rats (SHR) & $\begin{array}{l}1,5,15,30 \text {, or } 60 \mathrm{mg} / \mathrm{kg} \mathrm{CBD} \text {, i.p. } \\
\text { injection } 30 \text { min prior to social } \\
\text { interaction test }\end{array}$ & - & Almeida et al., 2013 \\
\hline $\begin{array}{l}\text { MK-801 (acute, } 0.3 \text { or } 0.6 \text { mg/kg), male } \\
\text { Sprague Dawley rats }\end{array}$ & $\begin{array}{l}1 \text { or } 3 \mathrm{mg} / \mathrm{kg} \mathrm{CBD} \text {, i.p. injection } 20 \mathrm{~min} \\
\text { prior to } \mathrm{MK}-801 \text { administration. Social } \\
\text { interaction test started } 20 \mathrm{~min} \text { after the } \\
\text { last injection }\end{array}$ & 3, 10 (partially) & Gururajan et al., 2011 \\
\hline $\begin{array}{l}\text { MK-801 (acute, } 0.3 \text { mg/kg), male } \\
\text { Sprague Dawley rats }\end{array}$ & $\begin{array}{l}1 \text { or } 3 \mathrm{mg} / \mathrm{kg} \mathrm{CBD} \text {, i.p. injection } 20 \mathrm{~min} \\
\text { prior to } \mathrm{MK}-801 \text { administration. } \\
\text { A modified social interaction test } \\
\text { started } 20 \text { min after the last injection }\end{array}$ & 3 & Gururajan et al., 2012 \\
\hline $\begin{array}{l}\text { MK-801 (chronic: } 1 \text { mg/kg, } 28 \text { days), } \\
\text { male C57BL/6J mice }\end{array}$ & $\begin{array}{l}30 \text { or } 60 \text { mg/kg CBD, i.p. injection } \\
30 \text { min prior to social interaction test }\end{array}$ & 60 & Gomes et al., 2015b \\
\hline $\begin{array}{l}\text { MK-801 (acute, } 0.08 \text { mg/kg), male } \\
\text { Wistar rats }\end{array}$ & $\begin{array}{l}5,12 \text {, or } 30 \text { mg/kg CBD, i.p. injection } \\
30 \text { min prior to } \mathrm{MK}-801 \text { administration. } \\
\text { Social interaction/recognition test } \\
\text { started } 30 \text { min after the last injection }\end{array}$ & - & Deiana et al., 2015 \\
\hline Male Nrg1 TM HET mice & $\begin{array}{l}\text { Chronic treatment with } 1,50 \text {, or } \\
100 \mathrm{mg} / \mathrm{kg} \text { CBD over } 3 \text { weeks }\end{array}$ & 50 (partially 1 and 100) & Long et al., 2012 \\
\hline $\begin{array}{l}\Delta^{9} \text {-THC }(1 \mathrm{mg} / \mathrm{kg}), \text { male Sprague } \\
\text { Dawley rats }\end{array}$ & $\begin{array}{l}5 \text { or } 20 \mathrm{mg} / \mathrm{kg} \text { CBD, i.p. injection } \\
20 \text { min prior to } \Delta^{9}-\mathrm{THC} \text { administration. } \\
\text { Social interaction test started } 20 \mathrm{~min} \\
\text { after the last injection }\end{array}$ & 20 & Malone et al., 2009 \\
\hline
\end{tabular}

TABLE 2 | Animal studies evaluating the effects of cannabidiol (CBD) on prepulse inhibition (PPI).

\begin{tabular}{|c|c|c|c|}
\hline Animal model & $\begin{array}{l}\text { Treatment regimen and test } \\
\text { procedure }\end{array}$ & Effective dose [mg/kg] & Reference \\
\hline Spontaneously hypertensive rats (SHR) & $\begin{array}{l}15,30 \text {, or } 60 \mathrm{mg} / \mathrm{kg} \text { CBD, i.p. } 30 \mathrm{~min} \\
\text { prior to PPI paradigm }\end{array}$ & 30 & Levin et al., 2014 \\
\hline $\begin{array}{l}\text { MK-801 (acute, } 0.3 \text { or } 0.6 \text { mg/kg), male } \\
\text { Sprague Dawley rats }\end{array}$ & $\begin{array}{l}\text { 3, } 10 \text {, or } 30 \mathrm{mg} / \mathrm{kg} \text { CBD, i.p. injection } \\
20 \text { min prior to } \mathrm{MK}-801 \text { administration. } \\
\text { PPI paradigm started } 20 \text { min after the } \\
\text { last injection }\end{array}$ & - & Gururajan et al., 2011 \\
\hline $\begin{array}{l}\text { MK-801 (chronic: } 1 \text { mg/kg, } 28 \text { days), } \\
\text { male C57BL/6J mice }\end{array}$ & $\begin{array}{l}30 \text { or } 60 \mathrm{mg} / \mathrm{kg} \text { CBD, i.p. treatment } \\
\text { began on } 6 \text { th day of MK- } 801 \\
\text { administration. PPI paradigm was } \\
\text { conducted on day } 29\end{array}$ & 30,60 & Gomes et al., 2015a \\
\hline $\begin{array}{l}\text { MK-801 (acute, } 1 \text { mg/kg), male } \\
\text { C57BL/6J mice }\end{array}$ & $\begin{array}{l}5 \mathrm{mg} / \mathrm{kg} \text { CBD, i.p. injection } 20 \text { min prior } \\
\text { to } \mathrm{MK}-801 \text { administration. PPI } \\
\text { paradigm started } 5 \text { min after the last } \\
\text { injection }\end{array}$ & 5 & Long et al., 2006 \\
\hline Male Nrg1 TM HET mice & $\begin{array}{l}\text { 1, 50, or } 100 \mathrm{mg} / \mathrm{kg} \text { CBD, i.p. over } \\
21 \text { days. PPI paradigm was done } \\
30-45 \text { min after the first injection and } \\
\text { on day } 21\end{array}$ & 100 (acute) & Long et al., 2012 \\
\hline $\begin{array}{l}\text { Amphetamine (acute, } 10 \mathrm{mg} / \mathrm{kg} \text { ) male } \\
\text { Swiss mice }\end{array}$ & $\begin{array}{l}15,30 \text {, or } 60 \mathrm{mg} / \mathrm{kg} \text { CBD, i.p. } 30 \mathrm{~min} \\
\text { prior to amphetamine injection. PPI } \\
\text { paradigm started } 30 \text { min after the last } \\
\text { injection }\end{array}$ & $15,30,60$ & Pedrazzi et al., 2015 \\
\hline
\end{tabular}

on startle amplitude and PPI, but acute administration of a high cannabidiol dosage $(100 \mathrm{mg} / \mathrm{kg})$ resulted in an increased startle amplitude (Long et al., 2012).

Such heterogeneous results were also observed in healthy rats. In Sprague Dawley rats, cannabidiol reduced startle amplitude (3 and 10 but not $30 \mathrm{mg} / \mathrm{kg}$ ) and PPI ( $10 \mathrm{mg} / \mathrm{kg}$ only) in a dosedependent manner (Gururajan et al., 2011), whereas the startle amplitude of Wistar rats was not influenced by acute cannabidiol $(15,30,60 \mathrm{mg} / \mathrm{kg})$ treatment, while higher dosages of cannabidiol $(30,60 \mathrm{mg} / \mathrm{kg}$ ) seemed to increase PPI (Levin et al., 2014).

Interestingly, animals with transmembrane Neuregulin 1 mutation, representing a genetic glutamatergic schizophrenia model, showed similar startle amplitude and PPI compared to their wild type like littermates. However, acute administration of 
$100 \mathrm{mg} / \mathrm{kg}$ cannabidiol increased not only the startle amplitude as observed in wild type like littermates, but also PPI. On the other hand, chronic cannabidiol treatment (1, 50, $100 \mathrm{mg} / \mathrm{kg} ; 21$ days) had no effect on startle amplitude and PPI in Nrg1 TM HET or their wild type like littermates (Long et al., 2012).

Pharmacological studies mimicking glutamatergic deficits of schizophrenia revealed that pretreatment with cannabidiol (5 mg/kg) reversed PPI disruption in C57BL/6JArc mice (Long et al., 2006). In addition, chronic cannabidiol treatment (30 or $60 \mathrm{mg} / \mathrm{kg}$ ) attenuated PPI impairments induced by chronic MK801 administration in C57BL/6J mice (Gomes et al., 2015a). While cannabidiol seems to be efficacious in treating PPI impairments in mice, pretreatment with cannabidiol had no effect on PPI deficits induced by acute MK-801-injection in Sprague Dawley rats (Gururajan et al., 2011).

However, acute cannabidiol treatment also reversed PPI deficits in two other animal models of aspects of schizophrenia. First, cannabidiol $(30 \mathrm{mg} / \mathrm{kg})$ reversed PPI deficit of SHR rats but had no effects on their reduced startle amplitude (Levin et al., 2014). Second, cannabidiol (15, 30, or $60 \mathrm{mg} / \mathrm{kg}$ ) attenuated the amphetamine-disruptive effects on PPI in male Swiss mice (Pedrazzi et al., 2015). Interestingly, the inhibition of anandamide hydrolysis by URB597 [selective fatty acid amide hydrolase (FAAH) inhibitor] had the same effect. Hence, the authors suggested that an increase of anandamide availability might be involved in the beneficial effects of cannabidiol.

In a nutshell, various studies showed that cannabidiol partially affected startle amplitude and PPI in healthy animals, while it had no effects in rats treated with MK-801, but reversed the PPI disruptive effects of MK-801 and amphetamine in mice as well as the PPI deficit of SHR rats.

These discrepancies, observed in both healthy wild type animals and animal models for aspects of schizophrenia, might be related to the different species/strain or experimental conditions applied. Therefore, more studies clarifying the potential antipsychotic effect of cannabidiol with regard to this specific behavioral deficit are desirable.

\section{Effect of Cannabidiol on Working Memory}

Various paradigms are available to test cognitive performance in animals. Two studies investigating the effects of cannabidiol on cognitive performance in $\Delta^{9}$-THC- or MK-801-treated animals, respectively, used paradigms based on object and/or spatial recognition. In addition, two further studies investigated the effects of cannabidiol-rich cannabis extracts in a spatial recognition task (Table 3).

The visuospatial Paired Associates Learning task (vsPAL) and the Self-Ordered Spatial Search (SOSS) task belong to the category of spatial recognition tasks that are frequently used in non-human primates. In rhesus monkeys, acute intramuscular $\Delta^{9}$-THC administration $(0.2$ and $0.5 \mathrm{mg} / \mathrm{kg})$ impaired overall trial completion accuracy and percent completed trials in the vsPAL with increasing trial-difficulty as well as trial completion accuracy in the SOSS task (Wright et al., 2013). Cannabidiol itself had no effect on cognitive performance. Interestingly, co-treatment with cannabidiol reversed the effects of $\Delta^{9}$ THC on vsPAL, but did not affect $\Delta^{9}$-THC-induced SOSS deficits.

These results are in line with a study assessing the effects of cannabidiol on novel object recognition (NOR) impairments in mice. The NOR task is often used in rodents and partially resembles vsPAL. While in vsPAL a familiar object and its former position has to be identified, NOR evaluates whether the animal recognizes a new unfamiliar object, as rodents tend to explore new objects more intensively than familiar ones. Cannabidiol (30 or $60 \mathrm{mg} / \mathrm{kg}$ ) significantly reversed the NOR performance impairments observed in male C57BL/6J mice chronically treated with MK-801, but had no effect per se (Gomes et al., 2015b).

Furthermore, Fadda et al. $(2004,2006)$ investigated the effects of cannabidiol-rich cannabis extracts in a water maze based delayed-matching-to-position task (DMTP). In the first trial, animals were placed onto a platform. In the second trial animals were released into the water and had to find the platform again. Cannabidiol-rich cannabis extracts did not affect the spatial working memory of rats, although these extracts also contained $\Delta^{9}$-THC. In particular the highest dose of $50 \mathrm{mg} / \mathrm{kg}$ cannabidiolrich extracts contained nearly $4 \mathrm{mg} / \mathrm{kg} \Delta^{9}$-THC, a dose that was sufficient to impair the working memory when given alone. Thus, the authors concluded that cannabidiol is able to antagonize the cognitive impairment. However, the cannabidiol-rich extracts did not reverse memory deficits when administered concurrently with the $\Delta^{9}$-THC-rich cannabis extracts. Therefore, it has been suggested, that the cannabidiol $/ \Delta^{9}-\mathrm{THC}$ ratio was not high enough to be effective (Fadda et al., 2004).

Interestingly, cannabidiol-rich extracts ( 5 and $10 \mathrm{mg} / \mathrm{kg}$ ) were also unable to reverse working memory deficits induced by MK801 in rats (Fadda et al., 2006). It might be that the cannabidiol dosage had simply been too low, as higher concentrations (30 or $60 \mathrm{mg} / \mathrm{kg}$ ) had been shown to be effective in mice (Gomes et al., 2015b). However, even higher dosages of cannabidiol may not reverse working memory deficits induced by MK-801 in rats due to interspecies differences.

Overall, the limited data available seem to suggest that cannabidiol has potential in ameliorating not only negative symptoms but also cognitive functions. However, as task-selective differences were observed, its effectiveness might be restricted to certain aspects of cognitive functions. Therefore, further studies analyzing the effects of cannabidiol on various cognitive aspects are called for.

\section{ANTIPSYCHOTIC POTENTIAL OF CANNABIDIOL: EVIDENCE FROM CLINICAL STUDIES}

The results of the first individual treatment attempt with cannabidiol were reported in Zuardi et al. (1995). Daily administration of up to $1500 \mathrm{mg} /$ day over 4 weeks resulted in decreased scores on the Brief Psychiatric Rating Scale (BPRS) and Interactive Observation Scale for Psychiatric Inpatients (IOSPI), indicating an overall improvement of psychotic symptoms. 
TABLE 3 | Animal studies evaluating the effects of cannabidiol (CBD) on working memory.

\begin{tabular}{|c|c|c|c|}
\hline Animal model & Treatment regimen and test procedure & $\begin{array}{l}\text { Effective dose } \\
{[\mathrm{mg} / \mathrm{kg}]}\end{array}$ & Reference \\
\hline $\begin{array}{l}\text { MK-801 (chronic: } 1 \mathrm{mg} / \mathrm{kg}, 28 \text { days), } \\
\text { male C57BL/6J mice }\end{array}$ & $\begin{array}{l}30 \text { or } 60 \text { mg/kg CBD, i.p. injection } 30 \text { min prior to novel } \\
\text { object recognition test }\end{array}$ & 30,60 & Gomes et al., 2015b \\
\hline $\begin{array}{l}\Delta^{9}-\mathrm{THC}(0.2,0.5 \mathrm{mg} / \mathrm{kg} \text { i.m. }) \text {, male } \\
\text { adults rhesus monkeys }\end{array}$ & $\begin{array}{l}0.5 \mathrm{mg} / \mathrm{kg} \text { CBD, i.m. concurrently with } \Delta^{9}-\mathrm{THC} \\
\text { administration. Visuospatial Paired Associates Learning } \\
\text { task and Self-Ordered Spatial Search started } 30 \text { min after } \\
\text { the injections }\end{array}$ & 0.5 (task selective) & Wright et al., 2013 \\
\hline $\begin{array}{l}\Delta^{9}-\mathrm{THC} \text {-rich and CBD-rich cannabis } \\
\text { extracts, male, adult Lister rats }\end{array}$ & $\begin{array}{l}\text { CBD-rich cannabis extracts }(0.5,5,10 \text {, or } 50 \mathrm{mg} / \mathrm{kg} \text { CBD } \\
\left.\text { and up to } 4 \mathrm{mg} / \mathrm{kg} \Delta^{9}-\mathrm{THC}\right) \text {, i.p. } 30 \mathrm{~min} \text { prior to Delayed } \\
\text { Matching to Sample task. In addition, CBD-rich cannabis } \\
\text { extracts were simultaneously injected with } \Delta^{9}-\mathrm{THC} \text {-rich } \\
\text { cannabis extract injection }\end{array}$ & $\begin{array}{c}50 \text { (as it contained } \\
\text { nearly } 4 \mathrm{mg} / \mathrm{kg} \\
\Delta^{9}-\mathrm{THC}\end{array}$ & Fadda et al., 2004 \\
\hline $\begin{array}{l}\text { MK-801 (0.1 mg/kg, acute), male, adult } \\
\text { Lister rats }\end{array}$ & $\begin{array}{l}\text { CBD-rich cannabis extracts ( } 5 \text { or } 10 \text { mg/kg CBD), i.p. } \\
\text { concurrently with MK-801 injection, } 30 \text { min prior to Delayed } \\
\text { Matching to Sample task. In addition, CBD-rich cannabis } \\
\text { extracts were simultaneously injected with } \Delta^{9} \text {-THC-rich } \\
\text { cannabis extract injection }\end{array}$ & - & Fadda et al., 2006 \\
\hline
\end{tabular}

Interestingly, the clinical improvement was not increased by additional treatment with haloperidol, a first generation antipsychotic. Nearly 10 years later, Zuardi et al. (2006) published a small case series of three patients. They were treated with increasing doses of cannabidiol (maximum $1280 \mathrm{mg} / \mathrm{kg}$ ) over 30 days. Importantly, one of these patients showed a slight improvement of both positive and negative symptoms. Interestingly, no side effects were reported in patients treated with cannabidiol. The first controlled, randomized, doubleblind clinical trial was conducted by Leweke et al. (2012). During this 4-week trial 42 schizophrenic patients received either cannabidiol (600-800 mg/day) or amisulpride (600$800 \mathrm{mg} /$ day) - a highly effective second generation antipsychotic, selectively antagonizing $\mathrm{D}_{2 / 3}$ receptors (Leucht et al., 2002). Both drugs resulted in significant clinical improvement of both positive and negative symptoms of psychosis. The efficacy of cannabidiol was comparable to that of amisulpride, but, importantly, cannabidiol revealed a superior side effect profile when compared to amisulpride. In particular, cannabidiol did not induce prolactin increase, weight gain, or extrapyramidal symptoms. Interestingly, in patients randomly allocated to cannabidiol treatment, the reduction of psychotic symptoms was significantly associated with an increase of anandamide levels in serum. This was exclusive for the cannabidiol treatment group and is in support for the hypothesis that cannabidiol's antipsychotic effect is at least in part mediated via anandamide and potentially related to a block of its metabolization or uptake.

As reviewed in Leweke et al. (2016), four additional clinical trials with schizophrenic patients have been initiated so far. Although to date data have not been published in a peer reviewed process, the sponsor of one recent clinical trial investigating the antipsychotic effects of cannabidiol (GW42003, $1000 \mathrm{mg} /$ day) as add-on medication in 88 patients suffering from schizophrenia or related disorders (e.g., schizoaffective or schizophrenia-like disorder) over a period of 6 weeks, announced that cannabidiol was consistently superior to placebo with regard to psychopathology while at the same time showing no relevant side-effect profile (GW Pharmaceuticals plc, 2015).
While cannabidiol seems to develop antipsychotic properties during at least 4 weeks of treatment, acute administration of cannabidiol (300 or $600 \mathrm{mg} / \mathrm{kg}$ ) did not affect selective attention studied in 28 schizophrenic outpatients (regularly treated with antipsychotics) using the Stroop Color Word Test (Hallak et al., 2010). However, there also were no side effects reported.

Although, only few data on the antipsychotic potential in schizophrenic patients are currently available (summarized in Table 4), they consistently indicate a promising efficacy and favorable side-effect profile of cannabidiol. However, large-scale clinical trials are still needed to evaluate the long-term efficacy and safety of this putative new antipsychotic.

\section{CANNABIDIOL: POTENTIAL MECHANISM OF ACTION}

The mode of action of cannabidiol is still not fully understood, although a plethora of possible mechanisms have been proposed.

Cannabidiol and $\Delta^{9}$-THC are the most important phytocannabinoids in the cannabis plant. Therefore, it has been hypothesized that both compounds might have the same molecular target, the cannabinoid receptors. However, several binding studies showed that cannabidiol has no significant affinity at $\mathrm{CB}_{1} \mathrm{R}$ and $\mathrm{CB}_{2} \mathrm{R}$ (Devane et al., 1988; Showalter et al., 1996; Thomas et al., 1998; Bisogno et al., 2001; Jones et al., 2010). In addition, most efficacy studies found no explicit receptor response (Matsuda et al., 1990; Petitet et al., 1998; Breivogel et al., 2001; Jones et al., 2010). In fact, it has been reported that cannabidiol acts as an antagonist of $\mathrm{CB}_{1} \mathrm{R}$ agonists such as WIN-55212 and CP-55940 (Petitet et al., 1998; Pertwee et al., 2002; Thomas et al., 2007). As cannabidiol also inhibited internalization of $\mathrm{CB}_{1} \mathrm{R}$ (Laprairie et al., 2014), it has been hypothesized that the observed antagonistic activity might be based on negative allosteric modulation of $\mathrm{CB}_{1} \mathrm{R}$ rather than on orthosteric binding (Laprairie et al., 2015). Consistent with these findings, Laprairie et al. (2015) provided evidence that in vitro 
cannabidiol behaves as a non-competitive negative allosteric modulator of $\mathrm{CB}_{1} \mathrm{R}$.

Owing to the observed significant association of the antipsychotic effect of cannabidiol with an increase of anandamide levels in serum (Leweke et al., 2012), it has been hypothesized that cannabidiol exerts its antipsychotic properties by moderately blocking $\mathrm{FAAH}$, resulting in an inhibition of anandamide and of related fatty acid ethanolamide (palmitoylethanolamide and oleoylethanolamide) degradation. In vitro, cannabidiol inhibited FAAH in mouse neuroblastoma cell (N18TG2) membrane preparations (Bisogno et al., 2001), mouse brain microsomes (Watanabe et al., 1996), as well as homogenates of rat brain membranes (De Petrocellis et al., 2011; Leweke et al., 2012). Moreover, it has been shown that cannabidiol blocks anandamide transporters, since it inhibited anandamide uptake by rat basophilic leukemia cells (RBL-2H3) (Rakhshan et al., 2000; Bisogno et al., 2001; De Petrocellis et al., 2011). So far, one possible anandamide transporter, termed FAAH-like anandamide transporter (FLAT) has been identified (Fu et al., 2012). As FLAT seems to be a splicing variant of the Faah-1 gene, it may be speculated that cannabidiol binds to similar binding sites of FAAH and FLAT proteins and is able to inhibit both, anandamide degradation and uptake. However, it has recently been reported that cannabidiol does not inhibit the human FAAH enzyme, but binds to fatty acid-binding proteins (FABPs) (Elmes et al., 2015), which seem to act as intracellular transporters of anandamide and other $N$-acylethanolamines (Kaczocha et al., 2009, 2012). Elmes et al. (2015) concluded that cannabidiol reduces anandamide inactivation in humans by competing with anandamide for FABPs binding. As long as FABPs are occupied by cannabidiol, anandamide cannot be transported to the FAAH enzyme, localized on the endoplasmic reticulum, resulting in elevated anandamide levels.

Although, various other molecular targets have been suggested to contribute to the antipsychotic effects of cannabidiol, their pharmacological relevance still needs to be evaluated in clinical trials.

On the one hand cannabidiol may facilitate $5-\mathrm{HT}_{1 A}$ receptor mediated serotonergic neurotransmission. In Chinese hamster ovary $(\mathrm{CHO})$ cells transfected with the human receptor, cannabidiol displaced the $5-\mathrm{HT}_{1 \mathrm{~A}}$ receptor agonist $[3 \mathrm{H}] 8-\mathrm{OH}-$ DPAT and increased [35S] GTP $\gamma$ S binding (Russo et al., 2005). On the other hand, cannabidiol did not displace [3H]8-OH-DPAT or stimulate $[35 \mathrm{~S}] \mathrm{GTP} \gamma \mathrm{S}$ binding in rat brainstem membrane preparations, while it increased the maximal efficacy of $8-\mathrm{OH}$ DPAT at $100 \mathrm{nmol} / \mathrm{L}$, but not at $1,10,31.6 \mathrm{nmol} / \mathrm{L}$ or $1 \mu \mathrm{mol} / \mathrm{L}$ (Rock et al., 2012). Interestingly, in mice, the anticataleptic effect of cannabidiol was prevented by the $5-\mathrm{HT}_{1 \mathrm{~A}}$ receptor antagonist WAY100635 (Gomes et al., 2013; Sonego et al., 2016). However, it remains unclear, whether the improvement of negative symptoms and cognitive deficits by cannabidiol involves $5-\mathrm{HT}_{1 \mathrm{~A}}$ receptor activation, as studies addressing this mechanism are lacking.

In addition, it has been reported that cannabidiol binds to the peroxisome proliferator-activated receptor gamma (PPAR $\gamma$ ) in vitro (O'Sullivan et al., 2009; Granja et al., 2012). PPAR $\gamma$ regulates the expression of genes related to lipid and glucose homeostasis as well as inflammatory responses. Thus, cannabidiol may ameliorate both observed disturbances of glucose metabolism and inflammatory/immune processes in schizophrenic patients (Holmes et al., 2006; Leza et al., 2015; Rajasekaran et al., 2015) by PPAR $\gamma$ activation.

The activation of transient receptor potential vanilloid type 1 receptors (TRPV1Rs) has also been suggested as mechanism of action, as cannabidiol stimulated TRPV1R in HEK293-cells transiently expressing human (Bisogno et al., 2001; Ligresti et al., 2006; De Petrocellis et al., 2011) or rat TRPV1R (Iannotti et al., 2014). In vivo, it has been shown that pretreatment with TRPV1R antagonist capsazepine blocked the ameliorating effect of cannabidiol on MK-801 induced PPI decrease (Long et al., 2006), indicating at least a partial involvement of TRPV1R activation. However, capsazepine also blocks calcium channels (Docherty et al., 1997) and nicotinic cholinergic receptors (Liu and Simon, 1997), thus other mechanisms might contribute to this effect as well. Since TRPV1Rs also mediate the perception of spiciness, it may be expected that receptor stimulation by systemic administration of cannabidiol result in such subjective perceptions, given that this mechanism is relevant in humans at the dosage used. Yet, this side effect has not been reported

TABLE 4 | Published clinical trials and case series evaluating the effects of cannabidiol in schizophrenic patients.

\begin{tabular}{|c|c|c|c|}
\hline Design & $\begin{array}{l}\text { Primary efficacy } \\
\text { endpoint }\end{array}$ & Outcome & Reference \\
\hline $\begin{array}{l}\text { Single case report, open-label, treatment-resistant } \\
\text { schizophrenia, up to } 1500 \mathrm{mg} / \text { day CBD over } 4 \text { weeks }\end{array}$ & $\begin{array}{l}\text { Psychotic symptoms } \\
\text { (BPRS; IOSPI) }\end{array}$ & Improvement in a treatment-resistant patient & Zuardi et al., 1995 \\
\hline $\begin{array}{l}\text { Open-label, case series (three patients), treatment-resistant } \\
\text { schizophrenia, up to } 1280 \mathrm{mg} / \text { day CBD over } 30 \text { days }\end{array}$ & $\begin{array}{l}\text { Psychotic symptoms } \\
\text { (BPRS) }\end{array}$ & $\begin{array}{l}\text { One patient showed mild improvement in } \\
\text { positive and negative symptoms }\end{array}$ & Zuardi et al., 2006 \\
\hline $\begin{array}{l}\text { Double-blind, active controlled acute trial, single CBD ( } 300 \\
\text { or } 600 \mathrm{mg} \text { ) or placebo administration }\end{array}$ & $\begin{array}{l}\text { Stroop Color Word Test } \\
\text { (SCWT) }\end{array}$ & $\begin{array}{l}\text { No beneficial effects of single CBD } \\
\text { administration on cognitive performance of } \\
\text { schizophrenic patients }\end{array}$ & Hallak et al., 2010 \\
\hline $\begin{array}{l}\text { Double-blind, active-controlled RCT with } 42 \text { acute } \\
\text { schizophrenic patients, 600-800 mg/day over } 4 \text { weeks }\end{array}$ & $\begin{array}{l}\text { Psychotic symptoms } \\
\text { (PANSS/BPRS) }\end{array}$ & $\begin{array}{l}\text { Significant clinical improvement compared to } \\
\text { baseline on days } 14 \text { and } 28 \text { for CBD and } \\
\text { amisulpride. Superior side-effect profile for CBD } \\
\text { compared to amisulpride }\end{array}$ & Leweke et al., 2012 \\
\hline
\end{tabular}

BPRS, Brief Psychiatric Rating Scale; CBD, cannabidiol; IOSPI, Interactive Observation Scale for Psychiatric Inpatients; PANSS, Positive and Negative Syndrome Scale; $R C T$, randomized clinical trial. 
or observed in clinical trials so far (e.g., Leweke et al., 2000, 2012). To date, evidence for a role of TRPV1R activation in schizophrenia is lacking, but TRPV1Rs may be indirectly involved in schizophrenia via its influence on dopaminergic (Tzavara et al., 2006) and glutamatergic neurotransmission (Fawley et al., 2014).

Furthermore, it has been suggested that cannabidiol targets GPR55 and GPR18 receptors, further subtypes of transient receptor potential receptors (TRPV2, TRPM8, TRPA1), $\alpha 3$ glycine receptors, adenosine receptors, $\mu$ and $\delta$ opioid receptors, nicotinic acetylcholine receptors, enzymes of the arachidonic acid cascade, ion channels like voltage-gated calcium channels or mitochondrial $\mathrm{Na}^{+} / \mathrm{Ca}^{2+}$ exchange, nitric oxide signaling and inflammatory cytokines (McPartland et al., 2014; Ibeas Bih et al., 2015). To date, the antipsychotic properties of cannabidiol cannot be directly linked to these possible targets. However, this does not mean that these mechanisms are not relevant for other medical conditions, e.g., epilepsy (Devinsky et al., 2014).

\section{CONCLUSION}

The antipsychotic potential of cannabidiol has been investigated in various behavioral paradigms and different animal models of aspects of schizophrenia. Although the results were partially inconsistent, they indicate that cannabidiol treatment ameliorates impairments of PPI, social interaction behavior and cognition in

\section{REFERENCES}

Adams, R. (1942). Marihuana: harvey lecture. Bull. N. Y. Acad. Med. 18, 705-730.

Adams, R., and Baker, B. R. (1940). Structure of cannabidiol. VII. A method of synthesis of a tetrahydrocannabinol which possesses marihuana activity. J. Am. Chem. Soc. 62, 2405-2408. doi: 10.1021/ja01866a041

Adams, R., Hunt, M., and Clark, J. H. (1940a). Structure of cannabidiol, a product isolated from the marihuana extract of minnesota wild hemp. I. J. Am. Chem. Soc. 62, 196-200. doi: 10.1021/ja01858a058

Adams, R., Loewe, S., Pease, D. C., Cain, C. K., Wearn, R. B., Baker, R. B., et al. (1940b). Structure of cannabidiol. VIII. Position of the double bonds in cannabidiol. Marihuana activity of tetrahydrocannabinols. J. Am. Chem. Soc. 62, 2566-2567. doi: 10.1021/ja01866a510

Adams, R., Wolff, H., Cain, C. K., and Clark, J. H. (1940c). Structure of cannabidiol. V. Position of the alicyclic double bonds. J. Am. Chem. Soc. 62, 2215-2219. doi: 10.1021/ja01865a085

Allentuck, S., and Bowman, K. M. (1942). The psychiatric aspects of marihuana intoxication. Am. J. Psychiatry 99, 248-251. doi: 10.1176/ajp.99.2.248

Almeida, V., Levin, R., Peres, F. F., Niigaki, S. T., Calzavara, M. B., Zuardi, A. W., et al. (2013). Cannabidiol exhibits anxiolytic but not antipsychotic property evaluated in the social interaction test. Prog. Neuropsychopharmacol. Biol. Psychiatry 41, 30-35. doi: 10.1016/j.pnpbp.2012.10.024

Almeida, V., Peres, F. F., Levin, R., Suiama, M. A., Calzavara, M. B., Zuardi, A. W., et al. (2014). Effects of cannabinoid and vanilloid drugs on positive and negative-like symptoms on an animal model of schizophrenia: the SHR strain. Schizophr. Res. 153, 150-159. doi: 10.1016/j.schres.2014.01.039

Arseneault, L., Cannon, M., Poulton, R., Murray, R., Caspi, A., and Moffitt, T. E. (2002). Cannabis use in adolescence and risk for adult psychosis: longitudinal prospective study. BMJ 325, 1212-1213. doi: 10.1136/bmj.325.7374.1212

Bhattacharyya, S., Fusar-Poli, P., Borgwardt, S., Martin-Santos, R., Nosarti, C., O'carroll, C., et al. (2009). Modulation of mediotemporal and ventrostriatal function in humans by Delta9-tetrahydrocannabinol: a neural basis for the effects of Cannabis sativa on learning and psychosis. Arch. Gen. Psychiatry 66, 442-451. doi: 10.1001/archgenpsychiatry.2009.17 rodents and rhesus monkeys. In addition, individual treatment attempts as well as one randomized, double-blind clinical study, demonstrated the antipsychotic potential of cannabidiol and its superior side effect profile compared to conventional antipsychotics. In addition, a recently conducted clinical trial investigating cannabidiol as an add-on medication showed promising results, although these have not yet been published in a peer reviewed process. Obviously more clinical trials are needed to substantiate the current findings, and in particular to investigate long-term efficacy and safety in larger cohorts.

However, cannabidiol seems to represent a mechanistically different and less side-effect prone antipsychotic compound for the treatment of schizophrenia, even though the underlying pharmacological mechanisms are still under debate. Nevertheless, the association between increased anandamide levels and reduced psychotic symptoms in schizophrenic patients treated with cannabidiol, points to a potentially new antipsychotic mechanism of action involving anandamide.

\section{AUTHOR CONTRIBUTIONS}

CR, JKM, BL, and FML performed the review of the literature and $\mathrm{CR}$ and FML drafted the manuscript with input from JKM and BL.

Bisogno, T., Hanus, L., De Petrocellis, L., Tchilibon, S., Ponde, D. E., Brandi, I., et al. (2001). Molecular targets for cannabidiol and its synthetic analogues: effect on vanilloid VR1 receptors and on the cellular uptake and enzymatic hydrolysis of anandamide. Br. J. Pharmacol. 134, 845-852. doi: 10.1038/sj.bjp.0704327

Breivogel, C. S., Griffin, G., Di Marzo, V., and Martin, B. R. (2001). Evidence for a new G protein-coupled cannabinoid receptor in mouse brain. Mol. Pharmacol. 60, 155-163.

Brown, A. S. (2011). The environment and susceptibility to schizophrenia. Prog. Neurobiol. 93, 23-58. doi: 10.1016/j.pneurobio.2010.09.003

Calzavara, M. B., Levin, R., Medrano, W. A., Almeida, V., Sampaio, A. P., Barone, L. C., et al. (2011). Effects of antipsychotics and amphetamine on social behaviors in spontaneously hypertensive rats. Behav. Brain Res. 225, 15-22. doi: 10.1016/j.bbr.2011.06.026

Calzavara, M. B., Medrano, W. A., Levin, R., Kameda, S. R., Andersen, M. L., Tufik, S., et al. (2009). Neuroleptic drugs revert the contextual fear conditioning deficit presented by spontaneously hypertensive rats: a potential animal model of emotional context processing in schizophrenia? Schizophr. Bull. 35, 748-759. doi: $10.1093 /$ schbul/sbn006

Cannon, M., and Jones, P. (1996). Schizophrenia. J. Neurol. Neurosurg. Psychiatry 60, 604-613. doi: 10.1136/jnnp.60.6.604

Corfas, G., Roy, K., and Buxbaum, J. D. (2004). Neuregulin 1-erbB signaling and the molecular/cellular basis of schizophrenia. Nat. Neurosci. 7, 575-580. doi: $10.1038 / \mathrm{nn} 1258$

De Petrocellis, L., Ligresti, A., Moriello, A. S., Allara, M., Bisogno, T., Petrosino, S., et al. (2011). Effects of cannabinoids and cannabinoid-enriched Cannabis extracts on TRP channels and endocannabinoid metabolic enzymes. Br. J. Pharmacol. 163, 1479-1494. doi: 10.1111/j.1476-5381.2010.01166.x

Deiana, S., Watanabe, A., Yamasaki, Y., Amada, N., Kikuchi, T., Stott, C., et al. (2015). MK-801-induced deficits in social recognition in rats: reversal by aripiprazole, but not olanzapine, risperidone, or cannabidiol. Behav. Pharmacol. 26, 748-765. doi: 10.1097/fbp.0000000000000178

Devane, W. A., Dysarz, F. A., Johnson, M. R., Melvin, L. S., and Howlett, A. C. (1988). Determination and characterization of a cannabinoid receptor in rat brain. Mol. Pharmacol. 34, 605-613. 
Devane, W. A., Hanus, L., Breuer, A., Pertwee, R. G., Stevenson, L. A., Griffin, G., et al. (1992). Isolation and structure of a brain constituent that binds to the cannabinoid receptor. Science 258, 1946-1949. doi: 10.1126/science.1470919

Devinsky, O., Cilio, M. R., Cross, H., Fernandez-Ruiz, J., French, J., Hill, C., et al. (2014). Cannabidiol: pharmacology and potential therapeutic role in epilepsy and other neuropsychiatric disorders. Epilepsia 55, 791-802. doi: 10.1111/epi.12631

Di Forti, M., Morgan, C., Dazzan, P., Pariante, C., Mondelli, V., Marques, T. R., et al. (2009). High-potency cannabis and the risk of psychosis. Br. J. Psychiatry 195, 488-491. doi: 10.1192/bjp.bp.109.064220

Di Forti, M., Sallis, H., Allegri, F., Trotta, A., Ferraro, L., Stilo, S. A., et al. (2014). Daily use, especially of high-potency cannabis, drives the earlier onset of psychosis in cannabis users. Schizophr. Bull. 40, 1509-1517. doi: $10.1093 / \mathrm{schbul} / \mathrm{sbt} 181$

Docherty, R. J., Yeats, J. C., and Piper, A. S. (1997). Capsazepine block of voltageactivated calcium channels in adult rat dorsal root ganglion neurones in culture. Br. J. Pharmacol. 121, 1461-1467. doi: 10.1038/sj.bjp.0701272

D'Souza, D. C., Abi-Saab, W. M., Madonick, S., Forselius-Bielen, K., Doersch, A., Braley, G., et al. (2005). Delta-9-tetrahydrocannabinol effects in schizophrenia: implications for cognition, psychosis, and addiction. Biol. Psychiatry 57, 594-608. doi: 10.1016/j.biopsych.2004.12.006

D’Souza, D. C., Perry, E., Macdougall, L., Ammerman, Y., Cooper, T., Wu, Y. T., et al. (2004). The psychotomimetic effects of intravenous delta9-tetrahydrocannabinol in healthy individuals: implications for psychosis. Neuropsychopharmacology 29, 1558-1572. doi: 10.1038/sj.npp.1300496

Elmes, M. W., Kaczocha, M., Berger, W. T., Leung, K., Ralph, B. P., Wang, L., et al. (2015). Fatty acid-binding proteins (FABPs) are intracellular carriers for Delta9-tetrahydrocannabinol (THC) and cannabidiol (CBD). J. Biol. Chem. 290, 8711-8721. doi: 10.1074/jbc.M114.618447

Emrich, H. M., Leweke, F. M., and Schneider, U. (1997). Towards a cannabinoid hypothesis of schizophrenia: cognitive impairments due to dysregulation of the endogenous cannabinoid system. Pharmacol. Biochem. Behav. 56, 803-807. doi: 10.1016/S0091-3057(96)00426-1

Fadda, P., Robinson, L., Fratta, W., Pertwee, R. G., and Riedel, G. (2004). Differential effects of THC- or CBD-rich cannabis extracts on working memory in rats. Neuropharmacology 47, 1170-1179. doi: 10.1016/j.neuropharm.2004.08.009

Fadda, P., Robinson, L., Fratta, W., Pertwee, R. G., and Riedel, G. (2006). Scopolamine and MK801-induced working memory deficits in rats are not reversed by CBD-rich cannabis extracts. Behav. Brain Res. 168, 307-311. doi: 10.1016/j.bbr.2005.11.022

Fawley, J. A., Hofmann, M. E., and Andresen, M. C. (2014). Cannabinoid 1 and transient receptor potential vanilloid 1 receptors discretely modulate evoked glutamate separately from spontaneous glutamate transmission. J. Neurosci. 34, 8324-8332. doi: 10.1523/jneurosci.0315-14.2014

Freedman, R. (2003). Schizophrenia. N. Engl. J. Med. 349, 1738-1749. doi: 10.1056/NEJMra035458

Fu, J., Bottegoni, G., Sasso, O., Bertorelli, R., Rocchia, W., Masetti, M., et al. (2012). A catalytically silent FAAH-1 variant drives anandamide transport in neurons. Nat. Neurosci. 15, 64-69. doi: 10.1038/nn.2986

Fusar-Poli, P., Crippa, J. A., Bhattacharyya, S., Borgwardt, S. J., Allen, P., MartinSantos, R., et al. (2009). Distinct Effects of \{Delta\}9-Tetrahydrocannabinol and Cannabidiol on Neural Activation During Emotional Processing. Arch. Gen. Psychiatry 66, 95-105. doi: 10.1001/archgenpsychiatry.2008.519

Gage, S. H., Hickman, M., and Zammit, S. (2016). Association between cannabis and psychosis: epidemiologic evidence. Biol. Psychiatry 79, 549-556. doi: 10.1016/j.biopsych.2015.08.001

Gaoni, Y., and Mechoulam, R. (1964). Isolation structure + partial synthesis of active constituent of hashish. J. Am. Chem. Soc. 86, 1646-1647. doi: 10.1021/ja01062a046

Gomes, F. V., Del Bel, E. A., and Guimaraes, F. S. (2013). Cannabidiol attenuates catalepsy induced by distinct pharmacological mechanisms via 5-HT1A receptor activation in mice. Prog. Neuropsychopharmacol. Biol. Psychiatry 46, 43-47. doi: 10.1016/j.pnpbp.2013.06.005

Gomes, F. V., Issy, A. C., Ferreira, F. R., Viveros, M. P., Del Bel, E. A., and Guimaraes, F. S. (2015a). Cannabidiol attenuates sensorimotor gating disruption and molecular changes induced by chronic antagonism of
NMDA receptors in mice. Int. J. Neuropsychopharmacol. 18:yu041. doi: 10.1093/ijnp/pyu041

Gomes, F. V., Llorente, R., Del Bel, E. A., Viveros, M. P., Lopez-Gallardo, M., and Guimaraes, F. S. (2015b). Decreased glial reactivity could be involved in the antipsychotic-like effect of cannabidiol. Schizophr. Res. 164, 155-163. doi: 10.1016/j.schres.2015.01.015

Granja, A. G., Carrillo-Salinas, F., Pagani, A., Gomez-Canas, M., Negri, R., Navarrete, C., et al. (2012). A cannabigerol quinone alleviates neuroinflammation in a chronic model of multiple sclerosis. J. Neuroimmune Pharmacol. 7, 1002-1016. doi: 10.1007/s11481-012-9399-3

Gururajan, A., Taylor, D. A., and Malone, D. T. (2011). Effect of cannabidiol in a MK-801-rodent model of aspects of schizophrenia. Behav. Brain Res. 222, 299-308. doi: 10.1016/j.bbr.2011.03.053

Gururajan, A., Taylor, D. A., and Malone, D. T. (2012). Cannabidiol and clozapine reverse MK-801-induced deficits in social interaction and hyperactivity in Sprague-Dawley rats. J. Psychopharmacol. 26, 1317-1332. doi: $10.1177 / 0269881112441865$

GW Pharmaceuticals plc (2015). GW Pharmaceuticals Announces Positive Proof of Concept Data in Schizophrenia. Available at: http://globenewswire.com/news-r elease/2015/09/15/768364/10149367/en/GW-Pharmaceuticals-Announces-Po sitive-Proof-of-Concept-Data-in-Schizophrenia.html $\mathrm{f}=22 \& \mathrm{fvtc}=3 \& \mathrm{fvtv}=$ 4000 [accessed June 28, 2016].

Hallak, J. E., Machado-De-Sousa, J. P., Crippa, J. A., Sanches, R. F., Trzesniak, C., Chaves, C., et al. (2010). Performance of schizophrenic patients in the Stroop Color Word Test and electrodermal responsiveness after acute administration of cannabidiol (CBD). Rev. Bras. Psiquiatr. 32, 56-61. doi: 10.1590/S151644462010000100011

Hanson, E., Healey, K., Wolf, D., and Kohler, C. (2010). Assessment of pharmacotherapy for negative symptoms of schizophrenia. Curr. Psychiatry Rep. 12, 563-571. doi: 10.1007/s11920-010-0148-0

Holmes, E., Tsang, T. M., Huang, J. T., Leweke, F. M., Koethe, D., Gerth, C. W., et al. (2006). Metabolic profiling of CSF: evidence that early intervention may impact on disease progression and outcome in schizophrenia. PLoS Med. 3:e327. doi: 10.1371/journal.pmed.0030327

Hopkins, M. E., Sharma, M., Evans, G. C., and Bucci, D. J. (2009). Voluntary physical exercise alters attentional orienting and social behavior in a rat model of attention-deficit/hyperactivity disorder. Behav. Neurosci. 123, 599-606. doi: $10.1037 / \mathrm{a} 0015632$

Howlett, A. C. (1984). Inhibition of neuroblastoma adenylate cyclase by cannabinoid and nantradol compounds. Life Sci. 35, 1803-1810. doi: 10.1016/0024-3205(84)90278-9

Iannotti, F. A., Hill, C. L., Leo, A., Alhusaini, A., Soubrane, C., Mazzarella, E., et al. (2014). Nonpsychotropic plant cannabinoids, cannabidivarin (CBDV) and cannabidiol (CBD), activate and desensitize transient receptor potential vanilloid 1 (TRPV1) channels in vitro: potential for the treatment of neuronal hyperexcitability. ACS Chem. Neurosci. 5, 1131-1141. doi: 10.1021/ cn5000524

Ibeas Bih, C., Chen, T., Nunn, A. V., Bazelot, M., Dallas, M., and Whalley, B. J. (2015). Molecular targets of cannabidiol in neurological disorders. Neurotherapeutics 12, 699-730. doi: 10.1007/s13311-015-0377-3

Jones, N. A., Hill, A. J., Smith, I., Bevan, S. A., Williams, C. M., Whalley, B. J., et al. (2010). Cannabidiol displays antiepileptiform and antiseizure properties in vitro and in vivo. J. Pharmacol. Exp. Ther. 332, 569-577. doi: 10.1124/jpet.109.159145

Jones, P. G., Falvello, L., Kennard, O., Sheldrick, G. M., and Mechoulam, R. (1977). Cannabidiol. Acta Crystallogr. B 33, 3211-3214. doi: 10.1107/S0567740877010577

Kaczocha, M., Glaser, S. T., and Deutsch, D. G. (2009). Identification of intracellular carriers for the endocannabinoid anandamide. Proc. Natl. Acad. Sci. U.S.A. 106, 6375-6380. doi: 10.1073/pnas.0901515106

Kaczocha, M., Vivieca, S., Sun, J., Glaser, S. T., and Deutsch, D. G. (2012) Fatty acid-binding proteins transport $\mathrm{N}$-acylethanolamines to nuclear receptors and are targets of endocannabinoid transport inhibitors. J. Biol. Chem. 287, 3415-3424. doi: 10.1074/jbc.M111.304907

Kahn, R. S., Sommer, I. E., Murray, R. M., Meyer-Lindenberg, A., Weinberger, D. R., Cannon, T. D., et al. (2015). Schizophrenia. Nat. Rev. Dis. Primers 1:15067. doi: 10.1038/nrdp.2015.67 
Kim, J. S., Kornhuber, H. H., Schmid-Burgk, W., and Holzmuller, B. (1980). Low cerebrospinal fluid glutamate in schizophrenic patients and a new hypothesis on schizophrenia. Neurosci. Lett. 20, 379-382. doi: 10.1016/0304-3940(80)90178-0

Koethe, D., Gerth, C. W., Neatby, M. A., Haensel, A., Thies, M., Schneider, U., et al. (2006). Disturbances of visual information processing in early states of psychosis and experimental delta-9-tetrahydrocannabinol altered states of consciousness. Schizophr. Res. 88, 142-150. doi: 10.1016/j.schres.2006.07.023

Koethe, D., Hoyer, C., and Leweke, F. M. (2009). The endocannabinoid system as a target for modelling psychosis. Psychopharmacology (Berl.) 206, 551-561. doi: 10.1007/s00213-009-1591-7

Laprairie, R. B., Bagher, A. M., Kelly, M. E., and Denovan-Wright, E. M. (2015). Cannabidiol is a negative allosteric modulator of the cannabinoid CB1 receptor. Br. J. Pharmacol. 172, 4790-4805. doi: 10.1111/bph.13250

Laprairie, R. B., Bagher, A. M., Kelly, M. E., Dupre, D. J., and Denovan-Wright, E. M. (2014). Type 1 cannabinoid receptor ligands display functional selectivity in a cell culture model of striatal medium spiny projection neurons. J. Biol. Chem. 289, 24845-24862. doi: 10.1074/jbc.M114.557025

Leucht, S., Pitschel-Walz, G., Engel, R. R., and Kissling, W. (2002). Amisulpride, an unusual "atypical" antipsychotic: a meta-analysis of randomized controlled trials. Am. J. Psychiatry 159, 180-190. doi: 10.1176/appi.ajp.159.2.180

Levin, R., Calzavara, M. B., Santos, C. M., Medrano, W. A., Niigaki, S. T., and Abilio, V. C. (2011). Spontaneously hypertensive rats (SHR) present deficits in prepulse inhibition of startle specifically reverted by clozapine. Prog. Neuropsychopharmacol. Biol. Psychiatry 35, 1748-1752. doi: 10.1016/j.pnpbp.2011.06.003

Levin, R., Peres, F. F., Almeida, V., Calzavara, M. B., Zuardi, A. W., Hallak, J. E., et al. (2014). Effects of cannabinoid drugs on the deficit of prepulse inhibition of startle in an animal model of schizophrenia: the SHR strain. Front. Pharmacol. 5:10. doi: 10.3389/fphar.2014.00010

Leweke, F. M. (2012). Anandamide dysfunction in prodromal and established psychosis. Curr. Pharm. Des. 18, 5188-5193. doi: 10.2174/13816121280288 4843

Leweke, F. M., Mueller, J. K., Lange, B., and Rohleder, C. (2016). Therapeutic potential of cannabinoids in psychosis. Biol. Psychiatry 79, 604-612. doi: 10.1016/j.biopsych.2015.11.018

Leweke, F. M., Piomelli, D., Pahlisch, F., Muhl, D., Gerth, C. W., Hoyer, C., et al. (2012). Cannabidiol enhances anandamide signaling and alleviates psychotic symptoms of schizophrenia. Transl. Psychiatry 2:e94. doi: 10.1038/tp.2012.15

Leweke, F. M., Schneider, U., Radwan, M., Schmidt, E., and Emrich, H. M. (2000). Different effects of nabilone and cannabidiol on binocular depth inversion in man. Pharmacol. Biochem. Behav. 66, 175-181. doi: 10.1016/S00913057(00)00201-X

Leweke, F. M., Schneider, U., Thies, M., Münte, T. F., and Emrich, H. M. (1999). Effects of synthetic $\Delta 9$-tetrahydrocannabinol on binocular depth inversion of natural and artificial objects in man. Psychopharmacology 142, 230-235. doi: $10.1007 / \mathrm{s} 002130050884$

Leza, J. C., Garcia-Bueno, B., Bioque, M., Arango, C., Parellada, M., Do, K., et al. (2015). Inflammation in schizophrenia: a question of balance. Neurosci. Biobehav. Rev. 55, 612-626. doi: 10.1016/j.neubiorev.2015.05.014

Ligresti, A., Moriello, A. S., Starowicz, K., Matias, I., Pisanti, S., De Petrocellis, L., et al. (2006). Antitumor activity of plant cannabinoids with emphasis on the effect of cannabidiol on human breast carcinoma. J. Pharmacol. Exp. Ther. 318, 1375-1387. doi: 10.1124/jpet.106.105247

Liu, L., and Simon, S. A. (1997). Capsazepine, a vanilloid receptor antagonist, inhibits nicotinic acetylcholine receptors in rat trigeminal ganglia. Neurosci. Lett. 228, 29-32. doi: 10.1016/S0304-3940(97)00358-3

Long, L. E., Chesworth, R., Huang, X. F., Mcgregor, I. S., Arnold, J. C., and Karl, T. (2010). A behavioural comparison of acute and chronic Delta9-tetrahydrocannabinol and cannabidiol in C57BL/6JArc mice. Int. J. Neuropsychopharmacol. 13, 861-876. doi: 10.1017/S146114570999 0605

Long, L. E., Chesworth, R., Huang, X. F., Wong, A., Spiro, A., Mcgregor, I. S., et al. (2012). Distinct neurobehavioural effects of cannabidiol in transmembrane domain neuregulin 1 mutant mice. PLoS ONE 7:e34129. doi: 10.1371/journal.pone.0034129

Long, L. E., Malone, D. T., and Taylor, D. A. (2006). Cannabidiol reverses MK-801induced disruption of prepulse inhibition in mice. Neuropsychopharmacology 31, 795-803. doi: 10.1038/sj.npp.1300838
Lu, H.-C., and Mackie, K. (2016). An introduction to the endogenous cannabinoid system. Biol. Psychiatry 79, 516-525. doi: 10.1016/j.biopsych.2015.07.028

Lutz, B., Marsicano, G., Maldonado, R., and Hillard, C. J. (2015). The endocannabinoid system in guarding against fear, anxiety and stress. Nat. Rev. Neurosci. 16, 705-718. doi: 10.1038/nrn4036

Malone, D. T., Jongejan, D., and Taylor, D. A. (2009). Cannabidiol reverses the reduction in social interaction produced by low dose $\operatorname{Delta}(9)$ tetrahydrocannabinol in rats. Pharmacol. Biochem. Behav. 93, 91-96. doi: 10.1016/j.pbb.2009.04.010

Mason, O., Morgan, C. J., Dhiman, S. K., Patel, A., Parti, N., Patel, A., et al. (2009). Acute cannabis use causes increased psychotomimetic experiences in individuals prone to psychosis. Psychol. Med. 39, 951-956. doi: 10.1017/s0033291708004741

Matsuda, L. A., Lolait, S. J., Brownstein, M. J., Young, A. C., and Bonner, T. I. (1990). Structure of a cannabinoid receptor and functional expression of the cloned cDNA. Nature 346, 561-564. doi: 10.1038/346561a0

McPartland, J. M., Duncan, M., Di Marzo, V., and Pertwee, R. (2014). Are cannabidiol and Delta -tetrahydrocannabivarin negative modulators of the endocannabinoid system? A systematic review. Br. J. Pharmacol. 172, 737-753. doi: 10.1111/bph.12944

Mechoulam, R., Ben-Shabat, S., Hanus, L., Ligumsky, M., Kaminski, N. E., Schatz, A. R., et al. (1995). Identification of an endogenous 2-monoglyceride, present in canine gut, that binds to cannabinoid receptors. Biochem. Pharmacol. 50, 83-90. doi: 10.1016/0006-2952(95)00109-D

Mechoulam, R., Shani, A., Edery, H., and Grunfeld, Y. (1970). Chemical basis of hashish activity. Science 169, 611-612. doi: 10.1126/science.169.3945.611

Mechoulam, R., and Shvo, Y. (1963). Hashish-I : the structure of cannabidiol. Tetrahedron 19, 2073-2078. doi: 10.1016/0040-4020(63)85022-x

Moore, T. H., Zammit, S., Lingford-Hughes, A., Barnes, T. R., Jones, P. B., Burke, M., et al. (2007). Cannabis use and risk of psychotic or affective mental health outcomes: a systematic review. Lancet 370, 319-328. doi: 10.1016/S01406736(07)61162-3

Munro, S., Thomas, K. L., and Abu-Shaar, M. (1993). Molecular characterization of a peripheral receptor for cannabinoids. Nature 365, 61-65. doi: $10.1038 / 365061 \mathrm{a} 0$

Newell, K. A., Karl, T., and Huang, X. F. (2013). A neuregulin 1 transmembrane domain mutation causes imbalanced glutamatergic and dopaminergic receptor expression in mice. Neuroscience 248, 670-680. doi: 10.1016/j.neuroscience.2013.06.037

O’Sullivan, S. E., Sun, Y., Bennett, A. J., Randall, M. D., and Kendall, D. A. (2009). Time-dependent vascular actions of cannabidiol in the rat aorta. Eur. J. Pharmacol. 612, 61-68. doi: 10.1016/j.ejphar.2009.03.010

Pedrazzi, J. F., Issy, A. C., Gomes, F. V., Guimaraes, F. S., and Del-Bel, E. A. (2015). Cannabidiol effects in the prepulse inhibition disruption induced by amphetamine. Psychopharmacology (Berl.) 232, 3057-3065. doi: 10.1007/s00213-015-3945-7

Pertwee, R. G., Ross, R. A., Craib, S. J., and Thomas, A. (2002). (-)-Cannabidiol antagonizes cannabinoid receptor agonists and noradrenaline in the mouse vas deferens. Eur. J. Pharmacol. 456, 99-106. doi: 10.1016/S0014-2999(02)02624-9

Petitet, F., Jeantaud, B., Reibaud, M., Imperato, A., and Dubroeucq, M. C. (1998). Complex pharmacology of natural cannabinoids: evidence for partial agonist activity of delta9-tetrahydrocannabinol and antagonist activity of cannabidiol on rat brain cannabinoid receptors. Life Sci. 63, L1-L6. doi: 10.1016/S00243205(98)00238-0

Rajasekaran, A., Venkatasubramanian, G., Berk, M., and Debnath, M. (2015). Mitochondrial dysfunction in schizophrenia: pathways, mechanisms and implications. Neurosci. Biobehav. Rev. 48, 10-21. doi: 10.1016/j.neubiorev.2014.11.005

Rakhshan, F., Day, T. A., Blakely, R. D., and Barker, E. L. (2000). Carriermediated uptake of the endogenous cannabinoid anandamide in RBL-2H3 cells. J. Pharmacol. Exp. Ther. 292, 960-967.

Rock, E. M., Bolognini, D., Limebeer, C. L., Cascio, M. G., Anavi-Goffer, S., Fletcher, P. J., et al. (2012). Cannabidiol, a non-psychotropic component of cannabis, attenuates vomiting and nausea-like behaviour via indirect agonism of 5-HT(1A) somatodendritic autoreceptors in the dorsal raphe nucleus. Br. J. Pharmacol. 165, 2620-2634. doi: 10.1111/j.1476-5381.2011.01621.x

Rohleder, C., Wiedermann, D., Neumaier, B., Drzezga, A., Timmermann, L., Graf, R., et al. (2016). The functional networks of prepulse inhibition: neuronal 
connectivity analysis based on FDG-PET in awake and unrestrained rats. Front. Behav. Neurosci. 10:148. doi: 10.3389/fnbeh.2016.00148

Rubino, T., and Parolaro, D. (2016). The impact of exposure to cannabinoids in adolescence: insights from animal models. Biological Psychiatry 79, 578-585. doi: 10.1016/j.biopsych.2015.07.024

Russo, E. B., Burnett, A., Hall, B., and Parker, K. K. (2005). Agonistic properties of cannabidiol at 5-HT1a receptors. Neurochem. Res. 30, 1037-1043. doi: 10.1007/s11064-005-6978-1

Schwarcz, G., Karajgi, B., and Mccarthy, R. (2009). Synthetic $\Delta-9$ tetrahydrocannabinol (dronabinol) can improve the symptoms of schizophrenia. J. Clin. Psychopharmacol. 29, 255-258. doi: 10.1097/JCP.0b013 e3181a6bc3b

Sherif, M., Radhakrishnan, R., D'souza, D. C., and Ranganathan, M. (2016). Human laboratory studies on cannabinoids and psychosis. Biol. Psychiatry 79, 526-538. doi: 10.1016/j.biopsych.2016.01.011

Showalter, V. M., Compton, D. R., Martin, B. R., and Abood, M. E. (1996). Evaluation of binding in a transfected cell line expressing a peripheral cannabinoid receptor (CB2): identification of cannabinoid receptor subtype selective ligands. J. Pharmacol. Exp. Ther. 278, 989-999.

Snyder, M. A., and Gao, W. J. (2013). NMDA hypofunction as a convergence point for progression and symptoms of schizophrenia. Front. Cell Neurosci. 7:31. doi: $10.3389 /$ fncel.2013.00031

Sonego, A. B., Gomes, F. V., Del Bel, E. A., and Guimaraes, F. S. (2016). Cannabidiol attenuates haloperidol-induced catalepsy and c-Fos protein expression in the dorsolateral striatum via 5-HT1A receptors in mice. Behav. Brain Res. 309, 22-28. doi: 10.1016/j.bbr.2016.04.042

Stefansson, H., Sigurdsson, E., Steinthorsdottir, V., Bjornsdottir, S., Sigmundsson, T., Ghosh, S., et al. (2002). Neuregulin 1 and susceptibility to schizophrenia. Am. J. Hum. Genet. 71, 877-892. doi: 10.1086/342734

Stella, N., Schweitzer, P., and Piomelli, D. (1997). A second endogenous cannabinoid that modulates long-term potentiation. Nature 388, 773-778. doi: $10.1038 / 42015$

Thomas, A., Baillie, G. L., Phillips, A. M., Razdan, R. K., Ross, R. A., and Pertwee, R. G. (2007). Cannabidiol displays unexpectedly high potency as an antagonist of CB1 and CB2 receptor agonists in vitro. Br. J. Pharmacol. 150, 613-623. doi: 10.1038/sj.bjp.0707133

Thomas, B. F., Gilliam, A. F., Burch, D. F., Roche, M. J., and Seltzman, H. H. (1998). Comparative receptor binding analyses of cannabinoid agonists and antagonists. J. Pharmacol. Exp. Ther. 285, 285-292.

Todd, A. R. (1946). Hashish. Experientia 2, 55-60. doi: 10.1007/bf02163886

Tzavara, E. T., Li, D. L., Moutsimilli, L., Bisogno, T., Di Marzo, V., Phebus, L. A., et al. (2006). Endocannabinoids activate transient receptor potential vanilloid
1 receptors to reduce hyperdopaminergia-related hyperactivity: therapeutic implications. Biol. Psychiatry 59, 508-515. doi: 10.1016/j.biopsych.2005.08.019

van den Buuse, M. (2004). Prepulse inhibition of acoustic startle in spontaneously hypertensive rats. Behav. Brain Res. 154, 331-337. doi: 10.1016/j.bbr.2004.02.021

van Ree, J. M., Niesink, R. J., and Nir, I. (1984). delta 1-Tetrahydrocannabinol but not cannabidiol reduces contact and aggressive behavior of rats tested in dyadic encounters. Psychopharmacology (Berl.) 84, 561-565. doi: 10.1007/BF0043 1467

Watanabe, K., Kayano, Y., Matsunaga, T., Yamamoto, I., and Yoshimura, H. (1996). Inhibition of anandamide amidase activity in mouse brain microsomes by cannabinoids. Biol. Pharm. Bull. 19, 1109-1111. doi: 10.1248/bpb.19.1109

Wollner, H. J., Matchett, J. R., Levine, J., and Loewe, S. (1942). Isolation of a physiologically active tetrahydrocannabinol from Cannabis sativa Resin. J. Am. Chem. Soc. 64, 26-29. doi: 10.1021/ja01253a008

Wong, A. H. C., and Van Tol, H. H. M. (2003). Schizophrenia: from phenomenology to neurobiology. Neurosci. Biobehav. Rev. 27, 269-306. doi: 10.1016/S0149-7634(03)00035-6

Wright, M. J. Jr., Vandewater, S. A., and Taffe, M. A. (2013). Cannabidiol attenuates deficits of visuospatial associative memory induced by Delta(9) tetrahydrocannabinol. Br. J. Pharmacol. 170, 1365-1373. doi: 10.1111/bph.12199

Zammit, S., Allebeck, P., Andreasson, S., Lundberg, I., and Lewis, G. (2002). Self reported cannabis use as a risk factor for schizophrenia in Swedish conscripts of 1969: historical cohort study. BMJ 325:1199. doi: 10.1136/bmj.325.7374.1199

Zuardi, A. W., Hallak, J. E., Dursun, S. M., Morais, S. L., Sanches, R. F., Musty, R. E., et al. (2006). Cannabidiol monotherapy for treatment-resistant schizophrenia. J. Psychopharmacol. 20, 683-686. doi: 10.1177/0269881106060967

Zuardi, A. W., Morais, S. L., Guimarães, F. S., and Mechoulam, R. (1995). Antipsychotic Effect of Cannabidiol. J. Clin. Psychiatry 56, 485-486.

Conflict of Interest Statement: FML is a shareholder of curantis UG (ltd.). The other authors declare that the research was conducted in the absence of any commercial or financial relationships that could be construed as a potential conflict of interest.

Copyright (C) 2016 Rohleder, Müller, Lange and Leweke. This is an open-access article distributed under the terms of the Creative Commons Attribution License (CC BY). The use, distribution or reproduction in other forums is permitted, provided the original author(s) or licensor are credited and that the original publication in this journal is cited, in accordance with accepted academic practice. No use, distribution or reproduction is permitted which does not comply with these terms. 